\title{
Seroepidemiology of Hepatitis E Virus Infection in Patients Undergoing Maintenance Hemodialysis: A Systematic Review and Meta-Analysis
}

\section{Ahmad Tavakoli}

Iran University of Medical Sciences https://orcid.org/0000-0003-1857-0610

\section{Seyed Moayed Alavian}

Baqiyatallah University of Medical Sciences

\section{Mohsen Moghoofei}

Kermanshah University of Medical Sciences

\section{Shayan Mostafaei}

Tehran University of Medical Sciences

\section{Saeedeh Abbasi}

Iran University of Medical Sciences

Mohammad Farahmand ( $\nabla$ m_farahmand@razi.tums.ac.ir)

Department of Virology, School of Public Health, Tehran University of Medical Sciences, Tehran

1417613151, Iran https://orcid.org/0000-0002-9648-9298

\section{Research article}

Keywords: Hepatitis E, Hemodialysis, seroprevalence, Meta-Analysis, HEV

Posted Date: February 25th, 2020

DOl: https://doi.org/10.21203/rs.2.24435/v1

License: (c) (1) This work is licensed under a Creative Commons Attribution 4.0 International License.

Read Full License 


\section{Abstract}

Background: Hepatitis E virus (HEV) infection is an important emerging health issue in patients on hemodialysis (HD). To date, numerous studies have reported controversial findings regarding the seroprevalence of HEV among this high-risk group around the world. The aim of the present study was to estimate the overall seroprevalence of HEV in HD patients.

Methods: A systematic literature search was carried out using PubMed, Web of Science, Scopus, Embase, and Google scholar from inception to January 10, 2020 with standard keywords. Pooled seroprevalence estimates with $95 \%$ confidence intervals $(\mathrm{Cl})$ were calculated using a random intercept logistic regression model.

Results: A total of 56 studies met the inclusion criteria compromising $9483 \mathrm{HD}$ patients. The pooled seroprevalence of HEV was estimated $9.31 \%$ (95\% Cl: $6.83 \%-12.57 \%$ ). The seroprevalence of HEV was increased from $6.6 \%$ between the years of 1994 and 2000 to $11.13 \%$ from the year of 2016 to 2020 . Blood transfusion was associated with a nearly two-fold increase in the rate of HEV seropositivity (OR=1.99; 95\% Cl: $1.50-2.63, P$ value $<0.0001, \mathrm{I}^{2}=6.5 \%$ ).

Conclusions: Our results indicated an increased exposure of HD patients with HEV infection over the last decade. We concluded that blood transfusion, age and duration of HD are considerable risk factors for acquiring HEV infection among HD patients.

\section{Background}

Hepatitis E, which is due to infection with Hepatitis E virus (HEV), is an important public-health concern and the major etiologic agent of acute liver damage and inflammation in humans worldwide. It has been estimated that about 20 million people are infected with HEV globally each year, leading to a 3.3 million symptomatic cases and around 44,000 deaths [1]. In developing countries, HEV is mainly transmitted through the consumption of contaminated water and food due to poor hygiene conditions that results in large-scale outbreaks [2, 3]. In industrialized countries, transmission usually occurs via alternative routes, like the consumption of undercooked pork as a foodborne zoonosis, which likely contribute to the sporadic cases of acute hepatitis and fulminant hepatic failure, particularly among immunosuppressed individuals [4]. Transmission via blood transfusion and blood products such as packed red blood cells and platelets have also been demonstrated, especially in developed countries $[2,5]$.

Chronic kidney disease and resulting End-Stage Renal Disease (ESRD) have become recognized as serious challenges in the global public health, and hemodialysis (HD) continues to be the predominant therapeutic approach for treatment of ESRD patients in most countries. Peritoneal dialysis and renal transplantation are two other major types of renal replacement therapies for ESRD patients, provide $20 \%$ of overall dialysis treatment $[6,7]$. It is well known that patients on hemodialysis are at increased risk for acquiring viral infections, and sharing dialysis machines, frequent blood transfusions, repeated hospitalizations, and impaired cellular immunity make them particularly prone to blood-borne viruses [8]. 
In previous studies, it has documented that chronic liver diseases caused by the hepatitis $\mathrm{C}(\mathrm{HCV})$ and hepatitis B (HBV) viruses are more prevalent in HD and thalassemia major patients than the general population [8-11].

HEV infection is another emerging health issue in HD patients which can deteriorate patients' conditions. To date, there are some varying reports of the seroprevalence of HEV in HD patients from different countries worldwide. However, there is a need for an updated study reporting the pooled seroprevalence of HEV in this high-risk group. Hence, this systematic review and meta-analysis aimed at estimating the seroprevalence of anti-HEV antibodies among HD patients throughout the world.

\section{Methods}

\section{Search strategy}

We performed a systematic review and meta-analysis of the literature according to the Preferred Reporting Items for Systematic Reviews and Meta-Analyses (PRISMA) guideline [12]. The searches were limited to the English language studies reporting the seroprevalence of HEV among HD patients around the world. PubMed, Web of Science, Scopus, Embase, and Google scholar were searched from inception until January 10, 2020. Full details of the search strategy for each database are in Table 1. Bibliographies section of retrieved articles were also reviewed for additional relevant studies that were likely missed in the primary search. All identified articles were imported to the EndNote software version X8 (Thomson Reuters, California, USA) for further evaluation.

Table 1. The details of search terms for each database 


\begin{tabular}{|c|c|}
\hline Databases & Search criteria \\
\hline PubMed & $\begin{array}{l}\text { ("Renal Dialysis"[Mesh Terms] OR Dialyses, Renal OR Renal Dialyses OR Dialysis, Renal OR } \\
\text { Hemodialysis OR Hemodialyses OR Dialysis, Extracorporeal OR Dialyses, Extracorporeal OR } \\
\text { Extracorporeal Dialyses OR Extracorporeal Dialysis) AND ("Hepatitis E"[Mesh Terms] OR } \\
\text { "Hepatitis E virus"[Mesh Terms] OR Hepatitis, Water-Borne OR Hepatitides, Water-Borne OR } \\
\text { Hepatitis, Water Borne OR Water-Borne Hepatitides OR Water-Borne Hepatitis OR ET-NANBH } \\
\text { OR Hepatitis, Viral, Non-A, Non-B, Enterically-Transmitted OR Enterically-Transmitted Non-A, } \\
\text { Non-B Hepatitis OR Enterically Transmitted Non A, Non B Hepatitis OR Epidemic Non-A, Non-B } \\
\text { Hepatitis OR Epidemic Non A, Non B Hepatitis OR HEV) }\end{array}$ \\
\hline Embase & $\begin{array}{l}\text { ('hepatitis e'/exp OR 'enterically transmitted non a non b hepatitis' OR 'epidemic non a non b } \\
\text { hepatitis' OR 'hepatitis e' OR 'hepatitis e virus'/exp OR 'hev (hepatitis)' OR 'hepatitis e virus' OR } \\
\text { 'hepatitis virus e') AND ('hemodialysis'/exp OR 'blood dialysis' OR 'chronic haemodialysis' OR } \\
\text { 'chronic hemodialysis' OR 'chronic intermittent haemodialysis' OR 'chronic intermittent } \\
\text { hemodialysis' OR 'dialysis center' OR 'dialysis, blood' OR 'extracorporeal blood cleansing' OR } \\
\text { 'extracorporeal dialysis' OR 'haemodialysis' OR 'haemodialysis center' OR 'haemodialysis centre' } \\
\text { OR 'haemodialysis department' OR 'haemodialysis unit' OR 'haemodialysis units, hospital' OR } \\
\text { 'hemodialyse' OR 'hemodialysis' OR 'hemodialysis center' OR 'hemodialysis department' OR } \\
\text { 'hemodialysis unit' OR 'hemodialysis units, hospital' OR 'hemorenodialysis' OR 'hemotrialysate' } \\
\text { OR 'intermittent chronic haemodialysis' OR 'intermittent chronic hemodialysis' OR 'intermittent } \\
\text { haemodialysis' OR 'intermittent hemodialysis' OR 'renal dialysis') }\end{array}$ \\
\hline Scopus & $\begin{array}{l}\text { TITLE-ABS-KEY ( ( "hepatitis e" OR "enterically transmitted non a non b hepatitis" OR } \\
\text { "epidemic non a non b hepatitis" OR "hepatitis e" OR "hepatitis e virus" OR "hev } \\
\text { (hepatitis)" OR "hepatitis e virus" OR "hepatitis virus e") AND ( "hemodialysis" OR } \\
\text { "blood dialysis" OR "chronic haemodialysis" OR "chronic hemodialysis" OR "chronic } \\
\text { intermittent haemodialysis" OR "chronic intermittent hemodialysis" OR "dialysis center" } \\
\text { OR "dialysis, blood" OR "extracorporeal blood cleansing" OR "extracorporeal dialysis" OR } \\
\text { "haemodialysis" OR "haemodialysis center" OR "haemodialysis centre" OR } \\
\text { "haemodialysis department" OR "haemodialysis unit" OR "haemodialysis units, hospital" OR } \\
\text { "hemodialyse" OR "hemodialysis" OR "hemodialysis center" OR "hemodialysis } \\
\text { department" OR "hemodialysis unit" OR "hemodialysis units, hospital" OR } \\
\text { "hemorenodialysis" OR "hemotrialysate" OR "intermittent chronic haemodialysis" OR } \\
\text { "intermittent chronic hemodialysis" OR "intermittent haemodialysis" OR "intermittent } \\
\text { hemodialysis" OR "renal dialysis") ) }\end{array}$ \\
\hline $\begin{array}{l}\text { Web of } \\
\text { Science }\end{array}$ & $\begin{array}{l}\text { TS = ( "hepatitis e" } \text { OR "enterically transmitted non a non b hepatitis" } \\
\text { OR "epidemic non a } \\
\text { non b hepatitis" OR "hepatitis e" OR "hepatitis e virus" OR "hev (hepatitis)" OR } \\
\text { "hepatitis e virus" OR "hepatitis virus e" ) AND ( "hemodialysis" OR "blood dialysis" OR } \\
\text { "chronic haemodialysis" OR "chronic hemodialysis" OR "chronic intermittent haemodialysis" } \\
\text { OR "chronic intermittent hemodialysis" OR "dialysis center" OR "dialysis, blood" } \\
\text { "extracorporeal blood cleansing" OR "extracorporeal dialysis" OR "haemodialysis" } \\
\text { "haemodialysis center" OR "haemodialysis centre" OR "haemodialysis department" } \\
\text { "haemodialysis unit" OR "haemodialysis units, hospital" OR "hemodialyse" OR } \\
\text { "hemodialysis" OR "hemodialysis center" OR "hemodialysis department" } \\
\text { "hemodialysis unit" OR "hemodialysis units, hospital" OR "hemorenodialysis" OR } \\
\text { "hemotrialysate" OR " OR "intermittent chronic haemodialysis" OR "intermittent chronic } \\
\text { hemodialysis" OR "intermittent haemodialysis" OR "intermittent hemodialysis" OR "renal } \\
\text { dialysis")) }\end{array}$ \\
\hline
\end{tabular}

\section{Selection criteria}


The inclusion criteria were as follows: 1) studies reporting the seroprevalence rate of anti-HEV IgG among HD patients across the world; 2) conference abstracts, letters to editor, short communications, and English abstracts with sufficient data; 3 ) studies performed by enzyme-linked immunosorbent assay (ELISA) and western blot. Studies meeting one of the following criteria were excluded: 1 ) reviews and case reports; 2) studies investigating the seroprevalence rate of anti-HEV IgM among HD patients; 3) studies investigating the molecular prevalence of HEV in HD patients; 4) studies on patients under other types of dialysis such as peritoneal dialysis; 5) studies assessing the incidence of HEV among patients undergoing hemodialysis, like prospective studies.

\section{Data extraction}

Titles and abstracts were screened by two blinded reviewers, and studies which were obviously not relevant to the study were excluded. Then, the full-texts of all potentially eligible studies were obtained and further evaluated by two independent reviewers, and any disagreements were resolved by consultation with a third reviewer. For each study, we extracted data on the following variables: author name, publication year, study location, total sample size, gender and age of patients, duration of HD, detection method, number of HEV-positive cases, and a history of blood transfusion. The extracted data were imported into a predesigned Excel spreadsheet (Microsoft Corporation, Redmond, Washington, USA).

\section{Statistical methods}

To estimate the pooled HEV seroprevalence among HD patients, a random intercept logistic regression model was implemented [13]. The logit transformation was used to stabilize the variance and normalize their distribution, and the Clopper-Pearson method was applied to estimate the $95 \%$ exact confidence intervals (Cls) for proportions [14]. A standard continuity correction of 0.5 was added to the studies with prevalence of zero [15]. In order to explore the possible sources of heterogeneity, subgroup analyses were performed, based on the publication year, gender, age, detection method, study location, history of blood transfusion, and duration of HD. To measure the heterogeneity among the included publications, I-square statistics $\left(1^{2}\right)$ was performed, in which the result is presented as a percentage. $I^{2}$ values of $25 \%, 50 \%$, and $75 \%$ are indicative of low, moderate, and high levels of heterogeneity, respectively [16]. All statistical tests and time-trend graph production were performed using R package Meta [17] (version 4.9.9, R Foundation for Statistical Computing, Vienna, Austria), and $P$ values of less than 0.05 were considered statistically significant.

\section{Results}

\section{Literature search}

In the initial search, 615 articles were identified from five electronic international databases. A total of 277 duplicates was excluded, and then 338 articles were screened by title and abstract, which led to the elimination of 260 articles. The remaining 78 articles were checked for agreement with the inclusion and 
exclusion criteria by the full-text review. After full-text screening, 28 articles were excluded due to the following: 12 articles were not relevant to the subject, 10 articles were included duplicated data, four articles had no full-text available, one article was determined the incidence of HEV among HD patients, and one article was not presented sufficient data. In addition, six relevant articles were found and included by a manual search of the reference lists of the identified articles. Finally, 56 articles were included in this systematic review and meta-analysis. Figure 1 represents the process of literature retrieval and screening using a flow chart.

\section{Study characteristics}

In this meta-analysis, a total of 56 studies, including a total of 9483 patients from 20 countries were included. Publication date of articles was ranged from 1994 to 2020. The characteristics of eligible studies in this systematic review and meta-analysis are summarized in Table 2. The largest study [18] included 420 and the smallest [19] included 30 HD patients. Most studies investigating the seroprevalence of HEV among patients undergoing HD were from Iran $(n=11)$, Italy $(n=7)$, and Turkey $(n=6)$. Of the 56 studies included, 17 provided information on patients' sex, 7 studies provided information on patients' sex, 4 had information on duration of HD, and 6 studies presented data on history of blood transfusion. In total, $53.5 \%$ of the studies $(n=30)$ were performed before 2010 , and $46.5 \%$ of the studies $(n=26)$ were performed after 2010.

Table 2. Characteristics of studies included in the systematic review and meta-analysis 


\begin{tabular}{|c|c|c|c|c|c|c|c|}
\hline $\begin{array}{l}\text { Author } \\
\text { (Ref.) }\end{array}$ & Year & $\begin{array}{l}\text { Study } \\
\text { Location }\end{array}$ & $\begin{array}{l}\text { Sample } \\
\text { size }\end{array}$ & $\begin{array}{l}\text { Mean age } \\
\text { (year) }\end{array}$ & $\begin{array}{l}\text { Detection } \\
\text { method }\end{array}$ & $\begin{array}{l}\text { No. of HEV } \\
\text { seropositive } \\
\text { cases }\end{array}$ & $\begin{array}{l}\text { Mean duration } \\
\text { of HD (Month) }\end{array}$ \\
\hline Halfon [23] & 1994 & France & 147 & 62.3 & $\begin{array}{l}\text { ELISA/Western } \\
\text { blot }\end{array}$ & 16 & - \\
\hline $\begin{array}{l}\text { Knödler } \\
{[24]}\end{array}$ & 1994 & Germany & 150 & - & $\begin{array}{l}\text { ELISA/Western } \\
\text { blot }\end{array}$ & 5 & - \\
\hline Buti [25] & 1995 & Spain & 50 & - & $\begin{array}{l}\text { ELISA/Western } \\
\text { blot }\end{array}$ & 3 & - \\
\hline Cengiz [26] & 1996 & Turkey & 72 & 45.5 & ELISA & 10 & 56.4 \\
\hline Fabrizi [27] & 1996 & Italy & 204 & - & ELISA & 6 & - \\
\hline $\begin{array}{l}\text { Gessoni } \\
{[28]}\end{array}$ & 1996 & Italy & 193 & 59.5 & ELISA & 18 & - \\
\hline $\begin{array}{l}\text { Guiserix } \\
\text { [29] }\end{array}$ & 1996 & France & 62 & - & ELISA & 2 & - \\
\hline $\begin{array}{l}\text { Psichogiou } \\
\text { [18] }\end{array}$ & 1996 & Greece & 420 & 57.3 & ELISA & 27 & 61.4 \\
\hline Fabrizi [30] & 1997 & Italy & 204 & 61.1 & ELISA & 6 & 39 \\
\hline $\begin{array}{l}\text { Parana } \\
\text { [22] }\end{array}$ & 1997 & Brazil & 392 & - & ELISA & 0 & - \\
\hline $\begin{array}{l}\text { Abdel Hady } \\
{[31]}\end{array}$ & 1998 & Egypt & 96 & - & ELISA & 38 & - \\
\hline $\begin{array}{l}\text { Arins oy } \\
{[32]}\end{array}$ & 1998 & Turkey & 52 & - & ELISA & 9 & - \\
\hline $\begin{array}{l}\text { Gessoni } \\
{[33]}\end{array}$ & 1998 & Italy & 247 & - & ELISA & 23 & - \\
\hline $\begin{array}{l}\text { Dalekos } \\
{[34]}\end{array}$ & 1998 & Greece & 211 & - & $\begin{array}{l}\text { ELISA/Western } \\
\text { blot }\end{array}$ & 7 & - \\
\hline Sylvan [35] & 1998 & Sweden & 182 & - & ELISA & 11 & - \\
\hline $\begin{array}{l}\text { Agarwal } \\
{[36]}\end{array}$ & 1999 & India & 64 & 38 & ELISA & 26 & - \\
\hline Kilic [37] & 1999 & Turkey & 70 & - & ELISA & 4 & - \\
\hline $\begin{array}{l}\text { Mateos } \\
{[38]}\end{array}$ & 1999 & Spain & 63 & - & $\begin{array}{l}\text { ELISA/Western } \\
\text { blot }\end{array}$ & 4 & 62 \\
\hline Trinta [39] & 2001 & Brazil & 65 & 65.1 & ELISA & 4 & - \\
\hline Irshad [40] & 2002 & India & 58 & - & ELISA & 21 & - \\
\hline Ayoola [41] & 2002 & $\begin{array}{l}\text { Saudi } \\
\text { Arabia }\end{array}$ & 83 & 39 & ELISA & 6 & - \\
\hline $\begin{array}{l}\text { Kiesslich } \\
\text { [42] }\end{array}$ & 2002 & Brazil & 192 & - & ELISA & 1 & - \\
\hline Ding [43] & 2003 & Japan & 60 & 46.2 & ELISA & 18 & - \\
\hline Mitsui [44] & 2004 & Japan & 416 & 60.1 & ELISA & 39 & 91.2 \\
\hline $\begin{array}{l}\text { Stefanidis } \\
{[45]}\end{array}$ & 2004 & Greece & 351 & 60 & ELISA & 17 & 49 \\
\hline Lee [46] & 2005 & Taiwan & 400 & 57 & ELISA & 124 & 32 \\
\hline $\begin{array}{l}\text { Taremi } \\
{[47]}\end{array}$ & 2005 & Iran & 324 & 53.5 & ELISA & 24 & 53.45 \\
\hline $\begin{array}{l}\text { Kikuchi } \\
\text { [48] }\end{array}$ & 2006 & Japan & 300 & 60.1 & ELISA & 57 & 116.4 \\
\hline $\begin{array}{l}\text { Pourahmad } \\
\text { [49] }\end{array}$ & 2009 & Iran & 43 & 59.3 & ELISA & 3 & 108 \\
\hline Uçar [50] & 2009 & Turkey & 92 & 55 & ELISA & 19 & 66 \\
\hline
\end{tabular}




\begin{tabular}{|c|c|c|c|c|c|c|c|}
\hline Mina [51] & 2010 & Greece & 366 & 60.5 & ELISA & 15 & 49.2 \\
\hline $\begin{array}{l}\text { Khameneh } \\
{[52]}\end{array}$ & 2011 & Iran & 65 & - & ELISA & 22 & - \\
\hline $\begin{array}{l}\text { El Sayed } \\
\text { Zaki [19] }\end{array}$ & 2013 & Egypt & 30 & - & ELISA & 0 & - \\
\hline $\begin{array}{l}\text { Harrison } \\
{[53]}\end{array}$ & 2013 & $\begin{array}{l}\text { United } \\
\text { Kingdom }\end{array}$ & 76 & - & ELISA & 28 & - \\
\hline $\begin{array}{l}\text { Mobaien } \\
{[54]}\end{array}$ & 2013 & Iran & 93 & 57 & ELISA & 25 & - \\
\hline Scotto [55] & 2013 & Italy & 104 & 65.1 & $\begin{array}{l}\text { ELISA/Western } \\
\text { blot }\end{array}$ & 10 & - \\
\hline $\begin{array}{l}\text { Zekavat } \\
{[56]}\end{array}$ & 2013 & Iran & 80 & 55.69 & ELISA & 5 & 15.6 \\
\hline $\begin{array}{l}\text { Ben-Ayed } \\
{[57]}\end{array}$ & 2014 & Tunisia & 286 & 54.86 & ELISA & 29 & - \\
\hline $\begin{array}{l}\text { Kelishadi } \\
{[21]}\end{array}$ & 2014 & Iran & 149 & 56 & ELISA & 0 & - \\
\hline $\begin{array}{l}\text { Mousavi } \\
\text { [58] }\end{array}$ & 2014 & Iran & 47 & 55.27 & ELISA & 5 & - \\
\hline $\begin{array}{l}\text { Alavian } \\
\text { [59] }\end{array}$ & 2015 & Iran & 274 & 59.9 & ELISA & 78 & 34.6 \\
\hline $\begin{array}{l}\text { El Sayed } \\
\text { Zaki }[60]\end{array}$ & 2015 & Egypt & 96 & 46.6 & ELISA & 22 & - \\
\hline Eini [61] & 2015 & Iran & 153 & - & ELISA & 30 & 33 \\
\hline Scotto [62] & 2015 & Italy & 231 & - & $\begin{array}{l}\text { ELISA/Western } \\
\text { blot }\end{array}$ & 14 & - \\
\hline Debes [63] & 2016 & Argentina & 81 & - & ELISA & 8 & - \\
\hline $\begin{array}{l}\text { Hajiahmadi } \\
{[64]}\end{array}$ & 2016 & Iran & 149 & 55.09 & ELISA & 6 & - \\
\hline Pisano [65] & 2016 & Argentina & 82 & 60 & ELISA & 8 & - \\
\hline Naziri [66] & 2016 & Iran & 300 & 54 & ELISA & 12 & - \\
\hline Ricco [67] & 2016 & Italy & 88 & 74.3 & ELISA & 22 & - \\
\hline Yilmaz [68] & 2017 & Turkey & 66 & - & ELISA & 28 & - \\
\hline Sheng [20] & 2017 & China & 170 & - & ELISA & 82 & - \\
\hline Altuğlu [69] & 2018 & Turkey & 68 & 49.2 & ELISA & 1 & 37.9 \\
\hline $\begin{array}{l}\text { de Oliveira } \\
{[70]}\end{array}$ & 2018 & Brazil & 310 & - & $\begin{array}{l}\text { ELISA/Western } \\
\text { blot }\end{array}$ & 8 & - \\
\hline $\begin{array}{l}\text { Kuznetsova } \\
{[71]}\end{array}$ & 2018 & Estonia & 176 & 50.9 & $\begin{array}{l}\text { ELISA/Western } \\
\text { blot }\end{array}$ & 7 & - \\
\hline Lemos [72] & 2019 & Brazil & 286 & - & ELISA & 70 & - \\
\hline $\begin{array}{l}\text { Mrzljak } \\
{[73]}\end{array}$ & 2020 & Croatia & 394 & 70.5 & ELISA & 110 & - \\
\hline
\end{tabular}

\section{Seroprevalence of HEV infection among HD patients}

The pooled estimated seroprevalence of HEV infection in HD patients around the world was $9.31 \%$ (95\% Cl: $6.83 \%-12.57 \%)$, and the range was from $48.24 \%[20]$ to $0 \%[19,21,22]$ of the selected individual studies. The results of the heterogeneity test indicated a significant heterogeneity among all studies that 
were analyzed in this meta-analysis, so the random-effects model was used for pooling the data. The highest and lowest seroprevalence of HEV were found in HD patients from China and Brazil, respectively (48.24\%, $95 \% \mathrm{Cl}: 40.82 \%-55.73 \%$ vs $1.77 \%, 95 \% \mathrm{Cl}: 0.23 \%-12.31 \%)$. To explore responsible factors for heterogeneity, subgroup analysis was conducted. This analysis showed that diagnostic method, duration of HD, age, study year, and study location are responsible for heterogeneity.

We divided the individual studies into two time periods of publication, before and after 2010. The polled estimated seroprevalence of HEV infection before and after 2010 were different, $8.1 \%(95 \% \mathrm{Cl}$ : 5.36\%-12.05\%) and 10.94\% (95\% Cl: 6.91\%-16.89\%), respectively (Figure 2). However, the difference was not statistically significant $(P=0.3)$. Among studies performed after 2010 , the maximum and minimum seroprevalence of HEV among HD patients were found in China and Estonia, respectively $(48.24 \%, 95 \% \mathrm{Cl}$ : $40.82 \%-55.73 \%$ vs $3.98 \%$, $95 \%$ Cl: $1.91 \%-8.11 \%$ ).

The seroprevalence of HEV among patients with hemodialysis duration more than 60 months was significantly higher than those with hemodialysis duration less than 60 months (27.69\%, 95\%Cl: 20.69\%$35.99 \%$ vs $15.78 \%, 95 \% \mathrm{Cl}: 8.85 \%-26.57 \%$, respectively) $(P=0.06)$. Furthermore, the proportion of HEV seropositivity among male cases undergoing HD was slightly higher than female cases $(10.86 \%, 95 \% \mathrm{Cl}$ : $6.66 \%-17.20 \%$ vs $9.54 \%, 95 \% \mathrm{Cl}: 5.62 \%-15.74 \%$, respectively) $(P=0.7)$. With respect to HEV serodetection techniques in blood samples of HD patients, ELISA with or without western blot assay as a confirmatory test was used. HEV seroprevalences were 10.37\% (95\%Cl: 7.30\%-14.54\%) and 5.14\% (95\%Cl: $3.62 \%-$ 7.25\%) when ELISA and ELISA/western blot assays were used, respectively, and the difference was statistically significant $(P=0.005)$. Table 3 indicates more detailed information on the seroprevalence of HEV infection among HD patients for subgroups. In addition, our results showed that blood transfusion is associated with a nearly two-fold increase in the rate of HEV seropositivity $(\mathrm{OR}=1.99 ; 95 \% \mathrm{Cl}$ : 1.50-2.63, $P$ value $<0.0001, I^{2}=6.5 \%$ ) (Figure 3 ).

Table 3. Subgroup analysis of the seroprevalence of HEV infection in HD patients

NA: Not applicable; ELISA: enzyme-linked immunosorbent assay;

† Statistical significant 


\begin{tabular}{|c|c|c|c|c|c|}
\hline Characteristics & Categories & $\begin{array}{l}\text { No. of } \\
\text { Studies }\end{array}$ & $\begin{array}{l}\text { Pooled prevalence } \\
\text { (\%) }(95 \% \mathrm{CI})\end{array}$ & $\begin{array}{c}\text { Heterogeneity } \\
\text { test } \\
\mathrm{I}^{2} \%, p \text {-value }\end{array}$ & $\begin{array}{c}\text { Differences between } \\
\text { subgroups; } \chi^{2} \text { test } \\
(p \text {-value })\end{array}$ \\
\hline Overall & & 56 & $9.31(6.83-12.57)$ & $\begin{array}{l}95.9 \% \\
P<0.01\end{array}$ & \\
\hline \multirow[t]{2}{*}{$\begin{array}{l}\text { Diagnostic } \\
\text { method }\end{array}$} & ELISA & 47 & $10.37(7.30-14.54)$ & $\begin{array}{l}96.6 \% \\
P<0.01\end{array}$ & \multirow[t]{2}{*}{$P=0.005 \dagger$} \\
\hline & $\begin{array}{l}\text { ELISA/Western } \\
\text { blot }\end{array}$ & 9 & $5.14(3.62-7.25)$ & $\begin{array}{l}55.4 \%, \\
P=0.01\end{array}$ & \\
\hline \multirow[t]{2}{*}{$\begin{array}{c}\text { Duration of HD } \\
\text { (Month) }\end{array}$} & $60<$ & 4 & $15.78(8.85-26.57)$ & $\begin{array}{l}87.8 \%, \\
P<0.01\end{array}$ & \multirow[t]{2}{*}{$P=0.06$} \\
\hline & $60>$ & 2 & 27.69 (20.69-35.99) & $0 \%, P=0.1$ & \\
\hline \multirow[t]{2}{*}{ Age (Year) } & $40<$ & 6 & 4.91 (1.76-12.97) & $\begin{array}{l}52.9 \%, \\
P=0.09\end{array}$ & \multirow[t]{2}{*}{$P=0.1$} \\
\hline & $40>$ & 7 & $12.19(6.42-21.93)$ & $\begin{array}{l}94.9 \% \\
P<0.01\end{array}$ & \\
\hline \multirow[t]{2}{*}{ Gender } & Male & 17 & $10.86(6.66-17.20)$ & $\begin{array}{l}94.0 \%, \\
P=0.01\end{array}$ & \multirow[t]{2}{*}{$P=0.7$} \\
\hline & Female & 17 & $9.54(5.62-15.74)$ & $\begin{array}{l}91.5 \%, \\
P=0.01\end{array}$ & \\
\hline \multirow[t]{5}{*}{ Study year } & $1994-2000$ & 18 & $6.60(3.82-11.16)$ & $\begin{array}{l}92.9 \% \\
P<0.01\end{array}$ & \multirow[t]{5}{*}{$P=0.6$} \\
\hline & $2001-2005$ & 9 & 9.81 (4.54-19.93) & $\begin{array}{l}96.4 \% \\
P<0.01\end{array}$ & \\
\hline & $2006-2010$ & 4 & $10.77(5.16-21.12)$ & $\begin{array}{l}89.4 \% \\
P<0.01\end{array}$ & \\
\hline & 2011-2015 & 13 & $11.70(6.15-21.15)$ & $\begin{array}{l}95.5 \% \\
P<0.01\end{array}$ & \\
\hline & $2016-2020$ & 12 & $11.13(5.59-20.94)$ & $\begin{array}{l}96.8 \% \\
P<0.01\end{array}$ & \\
\hline \multirow[t]{16}{*}{ Study location } & Argentina & 2 & $9.82(6.10-15.42)$ & $0 \%, P=0.98$ & \multirow[t]{16}{*}{$P<0.0001 \dagger$} \\
\hline & Brazil & 5 & $1.77(0.23-12.31)$ & $\begin{array}{l}96.2 \% \\
P<0.01\end{array}$ & \\
\hline & China & 1 & $48.24(40.82-55.73)$ & NA, NA & \\
\hline & Croatia & 1 & $27.92(23.71-32.55)$ & NA, NA & \\
\hline & Egypt & 3 & $12.78(1.54-57.82)$ & $\begin{array}{l}96.6 \%, \\
P=0.05\end{array}$ & \\
\hline & Estonia & 1 & $3.98(1.91-8.11)$ & NA, NA & \\
\hline & France & 2 & $7.63(3.29-16.72)$ & $\begin{array}{l}28.2 \%, \\
P=0.09\end{array}$ & \\
\hline & Germany & 1 & $3.33(1.39-7.76)$ & NA, NA & \\
\hline & Greece & 4 & $4.90(3.86-6.19)$ & $0 \%, P=0.30$ & \\
\hline & India & 2 & $38.52(30.32-47.43)$ & $0 \%, P=0.62$ & \\
\hline & Iran & 11 & $9.11(4.53-17.49)$ & $\begin{array}{l}95.0 \% \\
P<0.01\end{array}$ & \\
\hline & Italy & 7 & $7.52(4.39-12.58)$ & $\begin{array}{l}85.8 \% \\
P<0.01\end{array}$ & \\
\hline & Japan & 3 & $17.26(9.87-28.44)$ & $\begin{array}{l}88.7 \%, \\
P<0.01\end{array}$ & \\
\hline & Saudi Arabia & 1 & $7.23(3.28-15.17)$ & NA, NA & \\
\hline & Spain & 2 & $6.19(2.98-12.43)$ & $0 \%, P=0.94$ & \\
\hline & Sweden & 1 & $6.04(3.38-10.58)$ & NA, NA & \\
\hline
\end{tabular}




\begin{tabular}{|c|c|c|c|c|}
\hline Taiwan & 1 & $31.00(26.66-35.70)$ & NA, NA \\
\cline { 2 - 5 } & Tunisia & 1 & $10.14(7.14-14.21)$ & NA, NA \\
\hline Turkey & 6 & $12.92(5.65-26.87)$ & $\begin{array}{l}89.6 \%, \\
P<0.01\end{array}$ \\
\cline { 2 - 5 } & $\begin{array}{c}\text { United } \\
\text { Kingdom }\end{array}$ & 1 & $36.84(26.79-48.18)$ & NA, NA \\
\hline
\end{tabular}

\section{Time trend analysis}

Time trend analysis was performed to investigate changes in the seroprevalence of HEV infection over time in the world (Figure 4). According to this analysis, the seroprevalence of HEV was the lowest (6.6\%; $95 \% \mathrm{Cl}: 3.82 \%-11.16 \%$ ) between the years of 1994 and 2000. Since 2001 until 2020, the number of HEVseropositive cases among HD patients dramatically was increased, and the seroprevalence was $11.13 \%$ (95\% Cl: 5.59\%-20.94\%) between the years of 2016 and 2020 (Table 3).

\section{Discussion}

The present study for the first time estimated the seroprevalence of HEV in HD patients in order to a systematic review and meta-analysis setting. Patients undergoing HD are characterized by abnormalities in both the adaptive and innate immune systems, making them susceptible to infections [74]. After cardiovascular complications, infections are the second major leading cause of death in HD patients [75]. Among the different blood-borne viral infections, hepatitis and human immunodeficiency viruses are the most common problems in HD units as well as general population [76]. Hepatitis $\mathrm{E}$ is generally considered as an acute self-limited liver disease with no progression to chronic stages. However, recent studies have shown that chronic HEV infection and cirrhosis may occur especially in immunocompromised individuals such as HD patients [77]. A recent meta-analysis performed on the association between HEV seroprevalence and hemodialysis showed that the seroprevalence is more prevalent in patients undergoing HD than non-HD control [78].

One of the most important finding of our study is that the overall seroprevalence of HEV infection in patients on HD is increasing during the last years around the world, which should be considered as an emerging public health threat. According to our findings, the pooled seroprevalence of HEV among HD patients was $9.31 \%$, and the highest rate of seroprevalence was seen among Chinese patients, followed by Indian, British, and Taiwanese patients. It is interesting that some European countries such as the United Kingdom and Croatia show a high seroprevalence of HEV among their HD patients. This can be explained by the fact that over the past decade, the incidence and prevalence of HEV infection, particularly with genotype 3 (G3) HEV, has been steadily growing in many developed countries, including countries of the European Union [79]. It should be noted that HEV G3 is more associated with the establishment of persistent infection in immunocompromised patients, leading to the development of chronic hepatitis and serious liver complications [80]. 
Our analysis suggested that the seroprevalence of HEV in HD units varies throughout the world. In the past, it was thought that HEV infection was limited to developing countries with poor hygiene and sanitary conditions. Nowadays, this assumption has been challenged, because the most developed countries are also experiencing a high prevalence rate of HEV. As an explanation, differences in culinary culture in different regional areas can result in the wide variety of the HEV prevalence. In developed countries, transmission of HEV to humans occurs mainly via consumption of raw pork products, particularly pork liver [81]. It was documented that zoonotic HEV G3 strains mostly circulate between humans, swine and wild boar in Europe [82].

Generally, immunization is an effective and safe measure in controlling infectious diseases, and HEV infection is not spared. There is no FDA-approved vaccine currently available against HEV and most HEV vaccine candidates are based on recombinant expressed HEV-capsid proteins. HEV 239 is an only recombinant HEV vaccine approved in China since 2011 which exhibited a high effectiveness to prevent HEV infection in the general population in China [83]. Therefore, vaccination schedule in HD patients can play an effective role to reduce HEV prevalence. Another suggestion for preventing hepatitis $\mathrm{E}$ transmission is taking preventive measures at the level of the community (e.g., water decontamination, improved hygiene and sanitation) and the personal (e.g., avoid eating raw or undercooked meat).

$\mathrm{HEV}$ is recognized as a serious public health concern in HD patients both in developed and developing countries. Generally, global immunization in humans and animals, especially in pigs, improvements in sanitation conditions in HEV-endemic areas, and avoiding the consumption of suspicious HEV-infested drinking water and undercooked shellfish, meat, vegetables and fruits can consider as the best strategies for decreasing the prevalence rate. On the other hand, it should be noted that our estimation can be affected by some limitation such as small number and low geographical coverage of the studies. Until now, there is no published data on the seroprevalence of HEV in this high-risk population in a large number of countries and performing updated investigations in these areas is highly suggested.

\section{Conclusions}

In conclusion, the overall seroprevalence of $\mathrm{HEV}$ in patients undergoing $\mathrm{HD}$ is increasing over the past years in the world, which should be considered as an emerging public health issue. We also demonstrated that blood transfusion is significantly associated with increased rate of HEV seropositivity. There are no data regarding the seroprevalence of HEV in HD patients in some countries, and therefore, it is highly recommended to perform screening tests for HEV in HD patients in other regions of the world to have more reliable estimates of overall seroprevalence of HEV.

\section{Abbreviations}

HEV: Hepatitis E virus; HD: hemodialysis; Cl: confidence interval; ESRD: End-Stage Renal Disease; HBV: Hepatitis B virus; HCV: Hepatitis C virus; ELISA: enzyme-linked immunosorbent assay. 


\section{Declarations}

\section{Ethics approval and consent to participate}

Not applicable

\section{Consent for publication}

Not applicable

\section{Availability of data and materials}

All data generated or analyzed during this study are included in this article.

\section{Competing interests}

The authors have no conflict of interest.

\section{Funding}

This study was not financially supported by any individual, agency, or institution.

\section{Authors 'contributions}

A.T and SM. A designed the study. M.F and S.M performed statistical analysis. A.T, M.M, and S.A wrote, reviewed and edited the manuscript. A.T and SM. A performed data interpretation. A.T, M.F, and S.A performed search strategy and data extraction. All authors involved in acquisition of data, read and approved the final draft.

\section{Acknowledgements}

Not applicable.

\section{References}

1. https://www.who.int/en/news-room/fact-sheets/detail/hepatitis-e.

2. Pérez-Gracia MT, García M, Suay B, Mateos-Lindemann ML: Current knowledge on hepatitis E. Journal of clinical and translational hepatology 2015, 3(2):117.

3. Hadifar S, Sedighi M, Mostafaei S, Miri A, Amiri H, Abiri R, Babaei F, Kabir K, Moghoofei M: Prevalence of hepatitis $E$ infection in the general population of Iran: a systematic review and meta-analysis. Future Virology 2017, 12(4):227-236.

4. Himmelsbach K, Bender D, Hildt E: Life cycle and morphogenesis of the hepatitis E virus. Emerging microbes \& infections 2018, 7(1):196. 
5. Sue PK, Pisanic N, Heaney CD, Forman M, Valsamakis A, Jackson AM, Ticehurst JR, Montgomery RA, Schwarz KB, Nelson KE: Hepatitis E virus infection among solid organ transplant recipients at a North American Transplant Center. In: Open forum infectious diseases: 2016: Oxford University Press; 2016.

6. Suri RS, Li L, Nesrallah GE: The risk of hospitalization and modality failure with home dialysis. Kidney international 2015, 88(2):360-368.

7. Ferraz FHRP, Rodrigues CIS, Gatto GC, Sá NMd: Differences and inequalities in relation to access to renal replacement therapy in the BRICS countries. Ciencia \& saude coletiva 2017, 22(7):2175-2185.

8. Ghorbani NR, Djalalinia S, Modirian M, Abdar ZE, Mansourian M, Gorabi AM, Asayesh H, Ansari $H$, Atoofi MK, Tajbakhsh R: Prevalence of hepatitis C infection in Iranian hemodialysis patients: an updated systematic review and meta-analysis. Journal of research in medical sciences: the official journal of Isfahan University of Medical Sciences 2017, 22.

9. Ashkani-Esfahani S, Alavian SM, Salehi-Marzijarani M: Prevalence of hepatitis C virus infection among hemodialysis patients in the Middle-East: A systematic review and meta-analysis. World journal of gastroenterology 2017, 23(1):151.

10. Bernieh B: Viral hepatitis in hemodialysis: An update. Journal of translational internal medicine 2015, 3(3):93-105.

11. Tavakoli A, Moghoofei M, Mostafaei S, Ghaffari H, Monavari SH, Alavian SM: Prevalence of hepatitis $B$ surface antigen among hemodialysis patients from Middle Eastern countries: a systematic review and meta-analysis. Future Virology 2017, 12(6):309-318.

12. Moher D, Liberati A, Tetzlaff J, Altman DG: Preferred reporting items for systematic reviews and meta-analyses: the PRISMA statement. Annals of internal medicine 2009, 151(4):264-269.

13. Stijnen T, Hamza TH, Özdemir P: Random effects meta-analysis of event outcome in the framework of the generalized linear mixed model with applications in sparse data. Statistics in medicine 2010, 29(29):3046-3067.

14. Newcombe RG: Two-sided confidence intervals for the single proportion: comparison of seven methods. Statistics in medicine 1998, 17(8):857-872.

15. Cox D: The continuity correction. Biometrika 1970:217-219.

16. Higgins JP, Thompson SG, Deeks JJ, Altman DG: Measuring inconsistency in meta-analyses. Bmj 2003, 327(7414):557-560.

17. Balduzzi S, Rücker G, Schwarzer G: How to perform a meta-analysis with R: a practical tutorial. Evidence-Based Mental Health 2019, 22(4):153-160.

18. Psichogiou M, Vaindirli E, Tzala E, Voudiclari S, Boletis J, Vosnidis G, Moutafis S, Skoutelis G, Hadjiconstantinou V, Troonen $\mathrm{H}$ : Hepatitis E virus (HEV) infection in haemodialysis patients. Nephrology Dialysis Transplantation 1996, 11(6):1093-1095.

19. El Sayed Zaki M, Magdy Abd El Razek H, Magdy Abd El Razek M: P46: Hepatitis E viral seroprevalence among multiple transfused Egyptian children. Journal of Viral Hepatitis 2013, 20:4041. 
20. Sheng X, Wang N: EPIDEMIOLOGY OF HEPATITIS E VIRUS INFECTION AMONG HEMODIALYSIS PATIENTS IN A SINGLE CENTER IN SHANGHAI. Nephrology Dialysis Transplantation 2017, 32.

21. Kelishadi M, Mojerloo M, Moradi A, Bazouri M, Hashemi P, Samadi S, Saeedi A, Tabarraei A: GB virus $\mathrm{C}$ viremia and anti-E2 antibody response among hemodialysis patients in Gorgan, Iran. Jundishapur journal of microbiology 2014, 7(11).

22. Parana R, Cotrim HP, Cortey-Boennec ML, Trepo C, Lyra L: Prevalence of hepatitis E virus IgG antibodies in patients from a referral unit of liver diseases in Salvador, Bahia, Brazil. Am J Trop Med Hyg 1997, 57(1):60-61.

23. Halfon P, Ouzan D, Chanas M, Khiri H, Feryn J, Mangin L, Masseyef M, Salvadori J: High prevalence of hepatitis E virus antibody in haemodialysis patients. Lancet (London, England) 1994, 344(8924):746-746.

24. Knödler B, Hiller J, Löliger C, Kühnl L: Hepatitis e antibodies in blood donors, hemodialysis patients and in normal people. Beitrage zur Infusionstherapie und Transfusionsmedizin= Contributions to infusion therapy and transfusion medicine 1994, 32:124-127.

25. Buti M, Jardí R, Cotrina M, Rodríguez-Frías F, Troonen H, Viladomiu L, Esteban J, Esteban R, Guardia $\mathrm{J}$ : Hepatitis E virus infection in acute hepatitis in Spain. Journal of virological methods 1995 , 55(1):49-54.

26. Cengiz K, Özyilkan E, Coşar AM, Günaydin M: Seroprevalence of hepatitis E in hemodialysis patients in Turkey. Nephron 1996, 74(4):730-730.

27. Fabrizi F, Lunghi G, Bacchini G, Guarnori I, Raffaele L, Erba G, Locatelli F: Low prevalence of hepatitis E virus antibody in haemodialysis patients: a seroepidemiological study. GIORNALE ITALIANO DI NEFROLOGIA 1996, 13:227-232.

28. Gessoni G, Manoni F: Hepatitis E virus infection in north-east Italy: serological study in the open population and groups at risk. Journal of viral hepatitis 1996, 3(4):197-202.

29. Guiserix J, Finielz P, Ramdane M, Rajaonarivelo P: Hepatitis E seroprevalence in dialysis in southern Reunion Island. Nephron 1996, 74(1):230-230.

30. Fabrizi F, Lunghi G, Bacchini G, Corti M, Pagano A, Locatelli F: Hepatitis E virus infection in haemodialysis patients: a seroepidemiological survey. Nephrology, dialysis, transplantation: official publication of the European Dialysis and Transplant Association-European Renal Association 1997, 12(1):133-136.

31. Abdel SH, El-Din M, El-Din M: A high hepatitis E virus (HEV) seroprevalence among unpaid blood donors and haemodialysis patients in Egypt. The Journal of the Egyptian Public Health Association 1998, 73(3-4):165-179.

32. Arinsoy T, Yilmaz M, Derici U, Sindel S: Prevalence of hepatitis E virus antibody in hemodialysis patients. Nephron 1998, 80(1):85.

33. Gessoni G, Rusca A, Valverde S, Antico F, Manoni F: Circulating anti-HEV antibodies: An Italian retrospective seroepidemiological study. European Journal of Laboratory Medicine 1998, 6(1):42-46. 
34. Dalekos G, Zervou E, Elisaf M, Germanos N, Galanakis E, Bourantas K, Siamopoulos K, Tsianos E: Antibodies to hepatitis $E$ virus among several populations in Greece: increased prevalence in an hemodialysis unit. Transfusion 1998, 38(6):589-595.

35. Sylvan SP, Jacobson SH, Christenson B: Prevalence of antibodies to hepatitis E virus among hemodialysis patients in Sweden. Journal of medical virology 1998, 54(1):38-43.

36. Agarwal S, Irshad M, Dash S: Prevalence of antibodies against hepatitis E virus in haemodialysis patients in India. Nephron 1999, 81(4):448.

37. Kilic H, Utas C, Oymak O, Unal A, Karagoz S, Sahin I: Investigation of hepatitis E virus antibodies in sera obtained from hemodialysis patients and healthy donors. Erciyes Tip Dergisi 1999, 21:80-82.

38. Mateos ML, Camarero C, Lasa E, Teruel JL, Mir N, Baquero F: Hepatitis E virus: relevance in blood donors and risk groups. Vox sanguinis 1999, 76(2):78-80.

39. Trinta KS, Liberto MIM, De Paula VS, Yoshida CF, Gaspar A: Hepatitis E virus infection in selected Brazilian populations. Memórias do Instituto Oswaldo Cruz 2001, 96(1):25-29.

40. Irshad M, Peter S, Agarwal SK, Choudhary PS: Viral hepatitis in multiple blood transfused patients treated at a referral hospital of Delhi, India. International Medical Journal 2002, 9(1):57-60.

41. Ayoola E, Want M, Gadour M, Al-Hazmi M, Hamza M: Hepatitis E virus infection in haemodialysis patients: A case-control study in Saudi Arabia. Journal of medical virology 2002, 66(3):329-334.

42. Kiesslich D, Rocha Jr J, Crispim M: Prevalence of hepatitis E virus antibodies among different groups in the Amazonian basin. Transactions of the Royal Society of Tropical Medicine and Hygiene 2002, 96(2):215-215.

43. Ding X, Li T-C, Hayashi S, Masaki N, Tran T-TH, Hirano M, Yamaguchi M, Usui M, Takeda N, Abe K: Present state of hepatitis E virus epidemiology in Tokyo, Japan. Hepatology research 2003, 27(3):169-173.

44. Mitsui T, Tsukamoto Y, Yamazaki C, Masuko K, Tsuda F, Takahashi M, Nishizawa T, Okamoto H: Prevalence of hepatitis $\mathrm{E}$ virus infection among hemodialysis patients in Japan: evidence for infection with a genotype 3 HEV by blood transfusion. Journal of medical virology 2004, 74(4):563572.

45. Stefanidis I, Zervou E, Rizos C, Syrganis C, Patsidis E, Kyriakopoulos G, Sdrakas L, Tsianas N, Rigopoulou E, Liakopoulos V: Hepatitis E virus antibodies in hemodialysis patients: an epidemiological survey in central Greece. The International journal of artificial organs 2004, 27(10):842-847.

46. Lee C-C, Shih Y-L, Laio C-S, Lin S-M, Huang M-M, Chen C-J, Chen C-P, Chang C-L, Chen L-R, Tschen S$Y$ : Prevalence of antibody to hepatitis E virus among haemodialysis patients in Taiwan: possible infection by blood transfusion. Nephron Clinical Practice 2005, 99(4):c122-c127.

47. Taremi M, Khoshbaten M, Gachkar L, EhsaniArdakani M, Zali M: Hepatitis E virus infection in hemodialysis patients: a seroepidemiological survey in Iran. BMC infectious diseases 2005, 5(1):36.

48. Kikuchi K, Yoshida T, Kimata N, Sato C, Akiba T: Prevalence of hepatitis E virus infection in regular hemodialysis patients. Therapeutic Apheresis and Dialysis 2006, 10(2):193-197. 
49. Pourahmad M, Sotoodeh AR, Nasiri H: Hepatitis E virus infection in hemodialysis patients: a seroepidemiological survey in Jahrom, Southern Iran. Hepat Mon 2009, 9(3):232-235.

50. Uçar E, Cetin M, Kuvandik C, Helvaci MR, Güllü M, Hüzmeli C: Hepatitis E virus seropositivity in hemodialysis patients in Hatay province, Turkey. Mikrobiyoloji bulteni 2009, 43(2):299-302.

51. Mina P, Georgiadou SP, Rizos C, Dalekos GN, Rigopoulou El: Prevalence of occult hepatitis B virus infection in haemodialysis patients from central Greece. World journal of gastroenterology: WJG 2010, 16(2):225.

52. Khameneh ZR, Sepehrvand N, Masudi S: Seroprevalence of hepatitis E among Iranian renal transplant recipients. Hepatitis monthly 2011, 11(8):646.

53. Harrison A, Scobie L, Crossan C, Parry R, Johnston P, Stratton J, Dickinson S, Ellis V, Hunter JG, Prescott OR: Hepatitis E seroprevalence in recipients of renal transplants or haemodialysis in southwest England: A case-control study. Journal of medical virology 2013, 85(2):266-271.

54. Mobaien A, Mohammadi R, Sorouri R, Sadeghi K: Hepatitis E virus seroprevalence in haemodialysis patients in Zanjan Province, Islamic Republic of Iran. 2013.

55. Scotto G, Martinelli D, Centra M, Querques M, Vittorio F, Carri PD, Tartaglia A, Campanale F, Bulla F, Prato R: Epidemiological and clinical features of HEV infection: a survey in the district of Foggia (Apulia, Southern Italy). Epidemiology \& Infection 2014, 142(2):287-294.

56. Zekavat OR, Makarem A, Karami MY, Amanat A, Mohandes M, Habibagahi M: Serological investigation for hepatitis $E$ virus infection in the patients with chronic maintenance hemodialysis from southwest of Iran. Asian journal of transfusion science 2013, 7(1):21.

57. Ben-Ayed Y, Hannachi H, Ben-Alaya-Bouafif N, Gouider E, Triki H, Bahri O: Hepatitis E virus seroprevalence among hemodialysis and hemophiliac patients in Tunisia (North Africa). Journal of medical virology 2015, 87(3):441-445.

58. Mousavi SSB, Motemednia F, Mousavi MB: Epidemiology of hepatitis e virus infection in patients on chronic hemodialysis. Jundishapur journal of microbiology $2014,7(5)$.

59. Alavian SM, Ataei B, Ebrahimi A, Pirhaji O, Azad R, Olya B, Ataei AM: Anti-hepatitis E antibody in hemodialysis patients in Isfahan, Iran: prevalence and risk factors. Hepatitis monthly 2015, 15(9).

60. Zaki MES, Abdelsalam M, Anbar NH, El-deek BS: Prevalence of hepatitis E virus among hemodialysis patients: one Egyptian Center Study. IJHSR 2015, 5:65-72.

61. Eini P, Mamani M, Javani M: Seroprevalence of hepatitis e among hemodialysis patients: a report from hamadan, iran. Hepatitis monthly 2015, 15(5).

62. Scotto G, Aucella F, Grandaliano G, Martinelli D, Querques M, Gesuete A, Infante B, Carri PD, Massa S, Salatino G: Hepatitis $E$ in hemodialysis and kidney transplant patients in south-east Italy. World Journal of Gastroenterology: WJG 2015, 21(11):3266.

63. Daniel Debes J, Martinez Wassaf M, Belen Pisano M, Marianelli LG, Lotto M, Coseano H, Balderramo D, Re V: HEPATITIS E INFECTION IN ARGENTINA, FROM IMMUNOCOMPETENT TO IMMUNOCOMPROMISED. In: AMERICAN JOURNAL OF TROPICAL MEDICINE AND HYGIENE: 2017: 
AMER SOC TROP MED \& HYGIENE 8000 WESTPARK DR, STE 130, MCLEAN, VA 22101 USA; 2017 : 240-241.

64. Hajiahmadi N, Moradi A, Vakili MA, Javid N, Kelishadi M, Bazouri M, Tabarraei A: Hepatitis E Virus Seroprevalence and Viremia in Hemodialysis and HIV Infected Patients in Iran. Iranian Journal of Virology 2016, 10(4):12-17.

65. Pisano MB, Balderramo D, Wassaf MM, Lotto M, Carlino Y, Ré VE, Debes JD: Hepatitis E virus infection in patients on dialysis and in solid organ transplant recipients in Argentina: exploring associated risk factors. Archives of virology 2016, 162(3):787-792.

66. Naziri H, Tahamtan A, Moradi A, Tabarraei A: Evaluation of anti-hepatitis E virus antibody among hemodialysis patients in Gorgan, north of Iran. Iranian Journal of Virology 2016, 10(2):13-18.

67. Ricco G, Bonino F, Lanza M, Scatena F, Alfieri CM, Messa P, Marchisio E, Mascolo G, Romanò L, Galli C: New immunoassays for total, IgA and IgM antibodies against hepatitis $E$ virus: Prevalence in Italian blood donors and patients with chronic liver or kidney diseases. Digestive and Liver Disease 2016, 48(5):536-541.

68. Yılmaz N, Çifci A, Balcı M, Kaya C, Cesur S, Uyar M, Sabah S, Erdoğan Y, İbiş M: The seroprevalance of hepatitis E, hepatitis G and TTV in haemodialysis patients. Ortadoğu Tıp Dergisi 2017, 9(1):6-11.

69. Altuğlu I, Yasar M, Zeytinoglu A, Özkahya M: Anti-Hepatitis E Antibody in Hemodialysis Patients. Turk Neph Dial Transpl 2018, 27(1):117-118.

70. de Oliveira JMNS, de Freitas NR, Teles SA, de Oliveira Bottino F, Lemos AS, de Oliveira JM, de Paula V, Pinto MA, Martins RMB: Prevalence of hepatitis E virus RNA and antibodies in a cohort of kidney transplant recipients in Central Brazil. International Journal of Infectious Diseases 2018, 69:41-43.

71. Kuznetsova TV, Ivanova-Pozdejeva A, Reshetnjak I, Geller J, Värv K, Rumvolt R, Vikentjeva M, Trubnikova EV, Pozdniakova NV, Shevelev AB: Hepatitis E virus infection in different groups of Estonian patients and people who inject drugs. Journal of Clinical Virology 2018, 104:5-10.

72. Lemos AS, Ribeiro CRdA, Barbosa JR, Lima DM, Colares JKB, Villar LM, Paula VSd: Hepatitis E virus prevalence among chronic kdney disease hemodialysis-dependent patients. 2019.

73. Mrzljak A, Dinjar-Kujundzic P, Knotek M, Kudumija B, llic M, Gulin M, Zibar L, Hrstic I, Jurekovic Z, Kolaric B: Seroepidemiology of hepatitis $E$ in patients on haemodialysis in Croatia. International Urology and Nephrology 2020:1-8.

74. Sharif MR, Chitsazian Z, Moosavian M, Raygan F, Nikoueinejad H, Sharif AR, Einollahi B: Immune disorders in hemodialysis patients. Iranian journal of kidney diseases 2015, 9(2):84.

75. Ito T, Maekawa H, Sakurada M, Orita H, Kushida T, Senuma K, Sato K: Risk factors for postoperative complications in patients on maintenance hemodialysis who undergo abdominal surgery. Asian journal of surgery 2016, 39(4):211-217.

76. Luma HN, Halle MP, Eloumou SAFB, Azingala F, Kamdem F, Donfack-Sontsa O, Ashuntantang G: Seroprevalence of human immunodeficiency virus, hepatitis $B$ and $C$ viruses among haemodialysis patients in two newly opened centres in Cameroon. The Pan African medical journal 2017, 27. 
77. Kamar N, Izopet J, Dalton HR: Chronic hepatitis E virus infection and treatment. Journal of clinical and experimental hepatology 2013,3(2):134-140.

78. Haffar S, Bazerbachi F, Leise M, Dillon J, Albright R, Murad MH, Kamath PS, Watt K: Systematic review with meta-analysis: the association between hepatitis $\mathrm{E}$ seroprevalence and haemodialysis. Alimentary pharmacology \& therapeutics 2017, 46(9):790-799.

79. Vina-Rodriguez A, Schlosser J, Becher D, Kaden V, Groschup MH, Eiden M: Hepatitis E virus genotype 3 diversity: phylogenetic analysis and presence of subtype 3b in wild boar in Europe. Viruses 2015, 7(5):2704-2726.

80. Gardinali NR, Guimarães JR, Melgaco JG, Kevorkian YB, de Oliveira Bottino F, Vieira YR, da Silva ACdA, Pinto DP, da Fonseca LB, Vilhena LS: Cynomolgus monkeys are successfully and persistently infected with hepatitis E virus genotype 3 (HEV-3) after long-term immunosuppressive therapy. PloS one 2017, 12(3).

81. Park W-J, Park B-J, Ahn H-S, Lee J-B, Park S-Y, Song C-S, Lee S-W, Yoo H-S, Choi I-S: Hepatitis E virus as an emerging zoonotic pathogen. Journal of veterinary science 2016, 17(1):1-11.

82. Thiry D, Rose N, Mauroy A, Paboeuf F, Dams L, Roels S, Pavio N, Thiry E: Susceptibility of pigs to zoonotic hepatitis $E$ virus genotype 3 isolated from a wild boar. Transboundary and emerging diseases 2017, 64(5):1589-1597.

83. Zhu F-C, Zhang J, Zhang X-F, Zhou C, Wang Z-Z, Huang S-J, Wang H, Yang C-L, Jiang H-M, Cai J-P: Efficacy and safety of a recombinant hepatitis $E$ vaccine in healthy adults: a large-scale, randomised, double-blind placebo-controlled, phase 3 trial. The Lancet 2010, 376(9744):895-902.

\section{Figures}




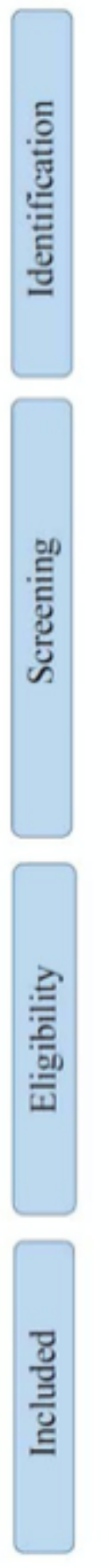

Records identified in Scopus,
ISI Web of Science, PubMed,
Embase, and Google scholar

$(n=615)$

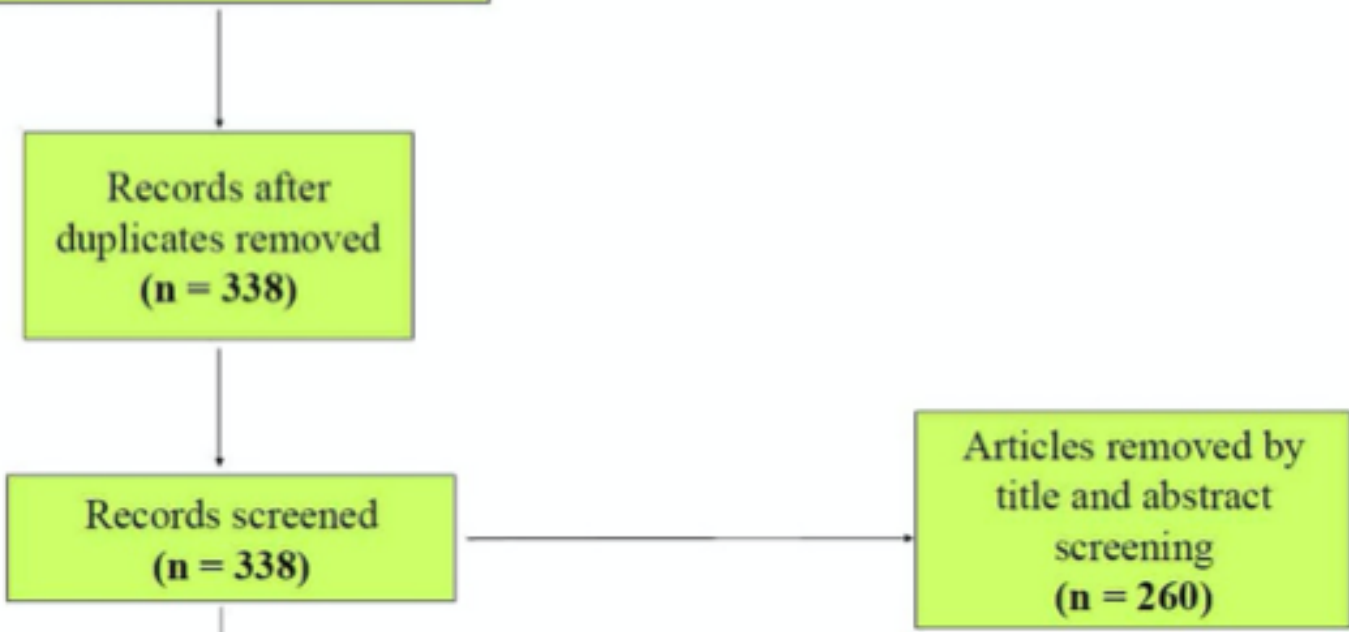

$(\mathrm{n}=\mathbf{2 6 0})$

Articles removed after full-text review

$$
\text { (n= 28) }
$$

12 articles were not relevant to the subject; 10 articles were included duplicated data; 4 articles had no full-text available;

1 article was determined the incidence of HEV among HD patients;

$\mathbf{1}$ article was not presented sufficient data;

Articles included by checking the reference lists of relevant studies

$$
(\mathrm{n}=6)
$$

\section{Figure 1}

Flowchart presenting the steps of literature search and selection 


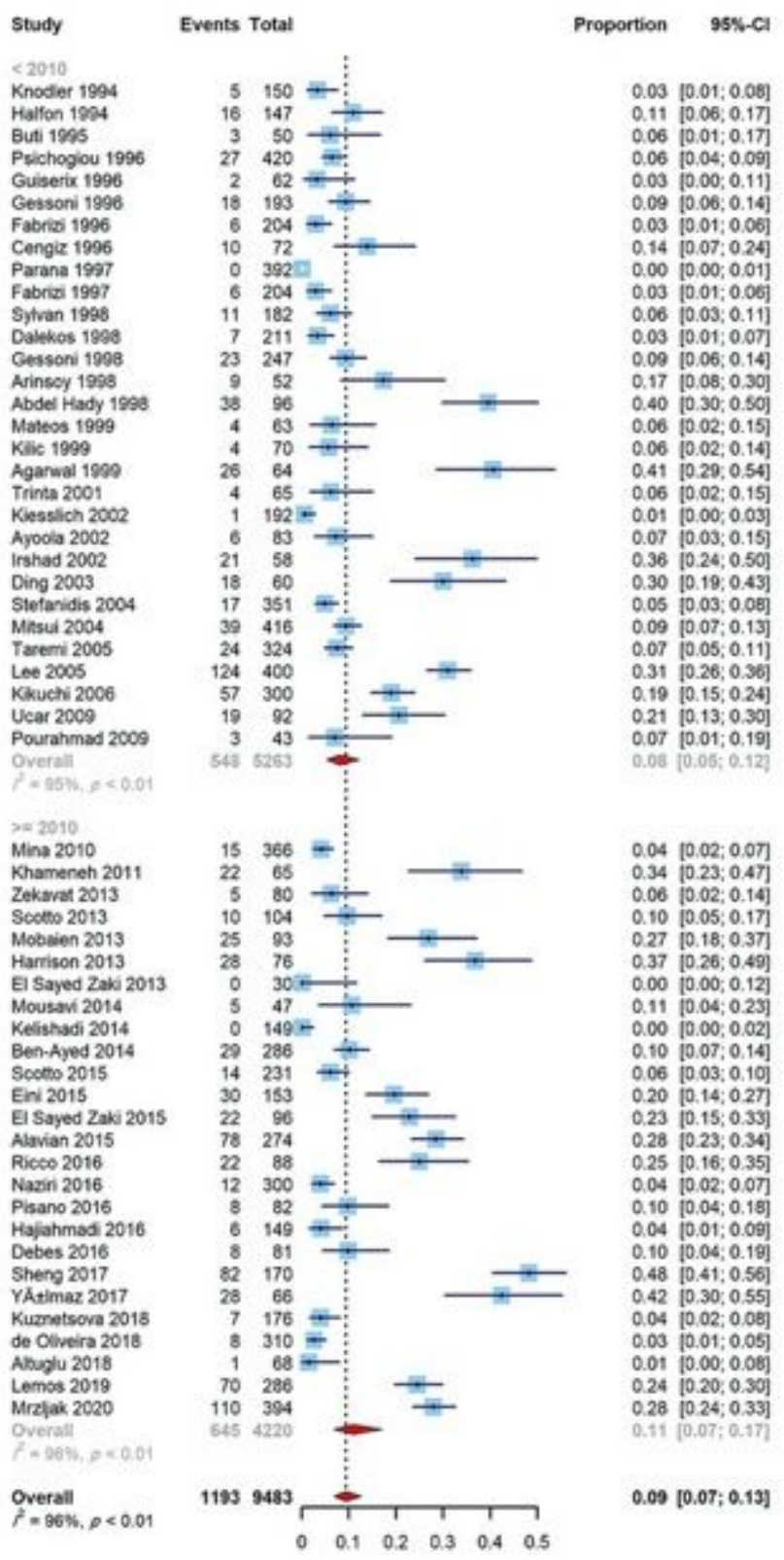

Figure 2

Forest plot of the seroprevalence of HEV infection among HD patients, according to the random effect model, stratified by study year (before and after 2010) 


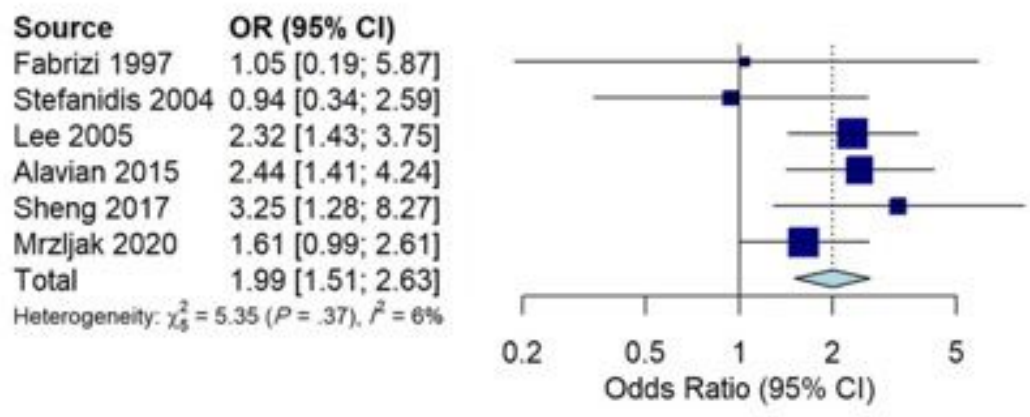

\section{Figure 3}

Forest plot of the association between blood transfusion and HEV seropositivity, according to the random effect model

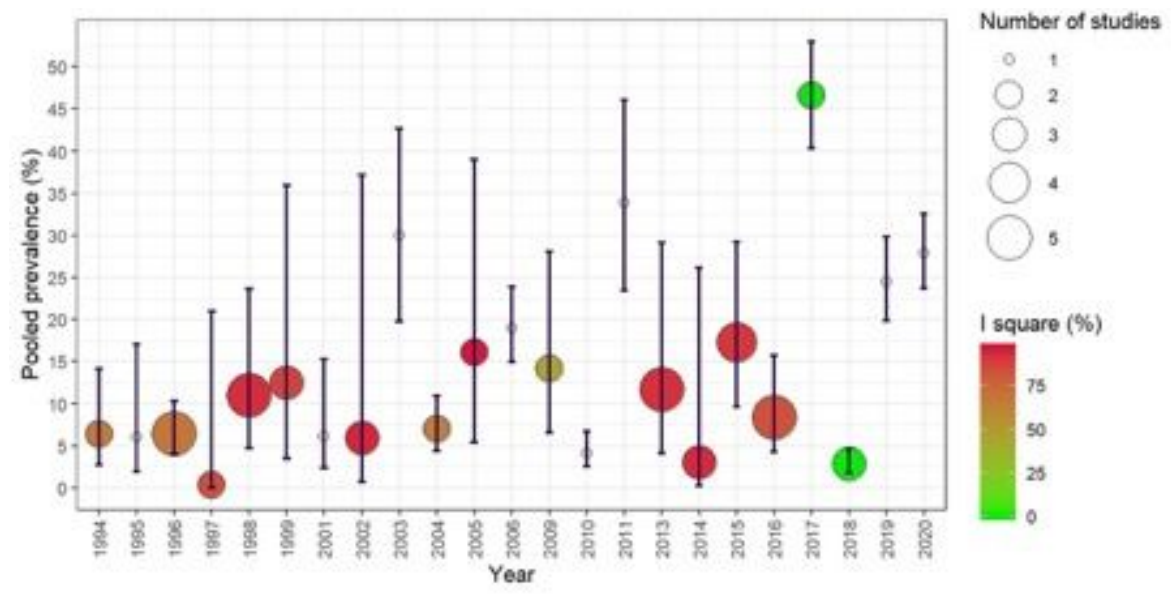

\section{Figure 4}

Time trend in the seroprevalence of HEV among HD patients 